\title{
ANTIHYPERTENSIVE EFFECT OF Harungana madagascariensis LAM. EX POIR. ON SODIUM FLUORIDE-INDUCED HYPERTENSION AND ASSOCIATED CARDIO- RENAL DYSFUNCTIONS
}

\author{
${ }^{1}$ Gbadamosi I. T., ${ }^{1}$ Okolo N. A., ${ }^{2}$ Oyagbemi A. A., ${ }^{2} *$ Ajibade T. O., ${ }^{3}$ Omobowale T. O. \\ 1Department of Botany, University of Ibadan, Nigeria. \\ 2Department of Veterinary Physiology and Biochemistry University of Ibadan. \\ 3Department of Veterinary Medicine, University of Ibadan. \\ *E-mail of corresponding author: toajibade@gmail.com; Tel: +2348181941873 \\ (Received: 12th January, 2020; Accepted: 24th March, 2020)
}

\section{ABSTRACT}

Hypertension is an important risk factor for cardiovascular diseases, which are major causes of mortality globally. This study evaluated the antihypertensive effects of Harungana madagascariensis on sodium fluorideinduced hypertension. Twenty-five rats were randomly divided into five groups (A-E). Group A (control), received normal food and water with no treatment; Groups B to E were exposed to $300 \mathrm{ppm}$ sodium fluoride $(\mathrm{NaF})$. In addition, Group C was treated with $10 \mathrm{mg} / \mathrm{kg}$ enalapril, while Groups D and E were treated with 100 $\mathrm{mg} / \mathrm{kg}$ and $200 \mathrm{mg} / \mathrm{kg}$ of $H$. madagascariensis extract, respectively. The result showed that there was a significant decrease in the systolic blood pressure (SBP), diastolic blood pressure (DBP) and mean arterial pressure (MAP) of the rats treated with $200 \mathrm{mg} / \mathrm{kg}$ of $\mathrm{H}$. madagascariensis compared with rats exposed to $\mathrm{NaF}$ alone. Also significant increase was observed in the activities of the enzymatic and non-enzymatic antioxidants in the cardiac and renal tissues of rats treated with $100 \mathrm{mg} / \mathrm{kg}$ and $200 \mathrm{mg} / \mathrm{kg}$ of H. madagascariensis extract similar to enalapril, compared with rats exposed to $\mathrm{NaF}$ alone. However, serum nitric oxide (NO) decreased significantly in rats exposed to $\mathrm{NaF}$ alone compared with rats that received $200 \mathrm{mg} / \mathrm{kg} \mathrm{H}$. madagascariensis as treatment. Blood urea nitrogen (BUN) and creatinine increased significantly in rats exposed to $\mathrm{NaF}$ alone compared with rats that received $200 \mathrm{mg} / \mathrm{kg} \mathrm{H}$. madagascariensis as treatment. The histopathology of the cardiac tissue of the rat exposed to $\mathrm{NaF}$ alone showed mild hydropic and vacuolar degeneration of cardiomyocytes, while the renal tissue showed foci of markedly flattened tubular epithelial cells and congestion of interstitial blood vessels. The aforementioned lesions were ameliorated in rats treated with $200 \mathrm{mg} / \mathrm{kg} \mathrm{H}$. Madagascariensis. In conclusion, $H$. madagascariensis had potent antihypertensive effect in rats. The effect was probably mediated via the alleviation of oxidative stress in cardiac and renal tissues.

Key words: Harungana madagascariensis, Antioxidant activity, Oxidative Stress, Hypotensive effect, Sodium fluoride.

\section{INTRODUCTION}

Hypertension in mammals is an abnormally elevated blood flow rate in the vasculature characterised by increased exertion of force by blood on a unit area of blood vessel. Hypertension strains the heart, injure blood vessels, increases the risk of heart attack, stroke, kidney problems and if untreated may cause death (Dayanand et al., 2015). Globally hypertension is an important risk factor for cardiovascular diseases, with people in subSaharan Africa more affected and likely to suffer one or more hypertension related diseases (Ogah, 2012). Indeed, it has already been projected that up to three quarters of the world's hypertensive population will be in economically- developing countries, such as Nigeria, by the year 2025 (Kearney et al., 2005). Hypertension may result from several aetiologies, including renal artery stenosis, pheochromocytoma, excessive adrenal aldosterone production (Carretero and Oparil,
2000), and inadvertent exposures to certain toxicants including lead, cadmium, organochlorine pesticides and polycyclic biphenyls (Kahn and Trasande, 2018). Similarly, drugs including steroids, sympathomimetic amines, immunosuppressive agents, nonsteroidal anti-inflammatory agents (NSAIDs), antidepressants and erythropoietin have been reported to induce hypertension or worsen preexisting hypertension (Gyamlani and Geraci, 2007).

Sodium fluoride $(\mathrm{NaF})$ is an environmental pollutant found in drinking water and is commonly included in tooth paste for its purported usefulness in the prevention of dental decay resulting from excessive acid formation and bacterial infection (Sadhukhan et al., 2016). Unfortunately, high concentrations of fluoride ion are deleterious to mammalian health and have 
been associated with interference with bone mineralisation and defects that are generally irreversible on the skeleton, teeth, and soft tissues (Suska, 2002). For instance, chronic fluoride exposure causes polycystic and some other kidney diseases and high exposure to sodium fluoride has also been reported to cause nervous system degenerations in animals (Barbier et al., 2010). Moreover, reports by various authors have suggested the induction of severe myocardial damage and disturbances of homeostasis in vital organs of mammals following prolonged exposure to sodium chloride (Ghosh et al., 2016). The deleterious effects of sodium fluoride are mediated via the induction of oxidative stress in various organs and tissues (Das et al., 2008), with consequent induction of varying degrees of abnormalities ranging from reduced functional capacities to end stage organ damage especially in the brain, heart, kidney and liver. Oxidative stress, which results from an imbalance between the formation and neutralization of pro-oxidants, has been implicated as an important modulator in the pathogenesis of hypertension (Farias etal., 2017).

Despite a diversity of pharmacological agents to treat hypertension, suboptimal control remains a significant problem in as many as $43 \%$ of patients with hypertension (Ayah et al., 2013). Consequently, especially in the last two to three decades, various medicinal plants have been and are being investigated for their potential beneficial effects on the management of hypertension because they are generally considered to be safe and usually not associated with the common side effects including headache, excessive urinary excretion of potassium, fatigue, cough and diarrhoea (Tabassum and Ahmad, 2011).

Harungana madagascariensis Lam. ex Poir commonly known as the dragon's blood tree, orange-milk tree or haronga, belongs to the family 'Hypericaceae' and the genus is monotypic being the sole member of the genus Harungana (Iwalewa et al., 2008). It is an herbal plant used traditionally in the treatment of many aliments such as malaria, jaundice, typhoid, asthma and ulcers (Moronkola et al., 2018). Documented scientific studies of $H$. madagascariensis indicate isolation of compounds like anthrones, anthraquinones, xanthones, flavonoids, and essential oils (Simeon et al., 2007). H. madagascariensis is a component of Jubi Formula, an herbal preparation which was found to restore the haematocrit and haemoglobin concentration in anaemic conditions and is a potential substitute for blood transfusion (Erah et al., 2003). Biapa et al. (2013) reported that $H$. madagascariensis could protect the red blood cells' membrane through its antioxidative properties. Moreover, Tom et al. (2018) reported potent vasodilatory activity for the stem bark of $H$. madagascariensis in isolated rat aorta. Furthermore, H. madagascariensis extract, reportedly, normalizes the activities of antioxidant enzymes such as superoxide dismutase and catalase in oxidative stress mediated organ specific injuries (Biapa et al., 2013). Therefore, this study was designed to investigate the modulatory role of H. madagascariensis in sodium fluoride-induced cardiovascular and renal dysfunctions in rats, with the purpose of obtaining more information on its potential benefit and probable development into a scientifically validated, safe and potent alternative to the currently available orthodox antihypertensive drugs.

\section{MATERIALS AND METHODS \\ Collection, Identification and Preparation of Plant Sample}

The stem bark of $H$. madagascariensis was collected from Moniya, a village within Akinyele Local Government Area, Ibadan with longitude 3.9152 ${ }^{\circ}$ $\mathrm{E}$ and latitude $7.5249^{\circ} \mathrm{N}$. The plant was identified at the University of Ibadan Herbarium (UIH) with voucher number UIH 22455. Thereafter, the stem bark was cut into small pieces, dried at room temperature and milled to a coarse powder. Two kilogram $(2 \mathrm{Kg})$ of the stem bark was soaked for about 48 hours in 2 L of water - methanol mixture (1:1 ratio) and then the suspension was filtered. Thereafter, the filtrate was concentrated using a rotary evaporator, as previously described by Njar (1993).

\section{Animals}

Male wistar rats (7 weeks old) were used for this study. They were kept in plastic cages under controlled light cycle (12 h light/12 h dark) and were allowed to acclimatize for two weeks at the animal house unit of the Department of Veterinary Physiology and Biochemistry, University of Ibadan, prior to further experiment. 
The rats were allowed free access to water and commercial pelletized rat feed ad libitum. The animals were humanely cared for according to the criteria outline in the Guide for the Care and the Use of Laboratory Animals prepared by the National Academy of Science and published by the National Institute of Health. During the experiment, ethics regulations were followed in accordance with the United States national and institutional guidelines for the protection of the animal's welfare (PHS, 1996). Ethical approval was obtained from the University of Ibadan Animal Care Use and Research Ethics Committee (UIACUREC/App/2015/011).

\section{Experimental Design}

Twenty five rats were divided into 5 groups, of five rats each, as follows: Group A (control), which received normal food and water with no treatment; Group B received normal food and water containing $300 \mathrm{ppm}$ sodium fluoride $(\mathrm{NaF})$; Group C was exposed to water containing 300 ppm sodium fluoride and $10 \mathrm{mg} / \mathrm{kg}$ body weight of enalapril was administered as treatment; Group $\mathrm{D}$ and Group E were also exposed to $300 \mathrm{ppm}$ sodium fluoride but received $100 \mathrm{mg} / \mathrm{kg}$ body weight and $200 \mathrm{mg} / \mathrm{kg}$ body weight of $H$. madagascariensis extract respectively. The experiment lasted for seven consecutive days.

\section{Determination of Blood Pressure}

Indirect blood pressure parameters (systolic, diastolic and mean blood pressure) were determined without anesthesia, by tail ple thys mography using a n electrosphygnomanometer (CODA, Kent Scientific, USA).

\section{Sample Collection}

Blood sample ( $3 \mathrm{ml}$ of blood) was collected from the retro-orbital venous plexus of the animals into plain sample bottles before they were humanely sacrificed by cervical dislocation. The blood was centrifuged at 4, $000 \times \mathrm{rpm}$ for $15 \mathrm{~min}$ to obtain the serum. The kidney and hearts were harvested and immediately placed on ice, rinsed, and homogenized in aqueous potassium phosphate buffer (0.1 M, pH 7.4) and the homogenate centrifuged at $10,000 \times \mathrm{rpm}\left(4^{\circ} \mathrm{C}\right)$ for $10 \mathrm{~min}$ to obtain the supernatant fraction.

\section{Chemicals and Reagents}

Reagents and chemicals used in this study included Biuret's reagent, Greiss reagent, phosphoric acid, sodium hydroxide, N 1 -Naphthyl ethylenediamine, sulphanilamide, distilled water, AST reagents kit, phosphate buffered saline, creatinine reagent, copper sulphate, trichloroacetic, reduced glutathione (GSH), thiobarbituric acid, ammonium ferrous sulphate, glacial acetic acid, potassium iodide, Ellman's reagent (DTNB), ethanol, urea reagent.

\section{Biochemical Assays}

The protein concentration of the various samples was determined using biuret method as described by Gornal et al. (1949). Briefly, $0.1 \mathrm{ml}$ of serum was placed into a test tube, $2.9 \mathrm{ml}$ distilled water was added and $3 \mathrm{ml}$ of working biuret reagent was also added. The tubes were placed in a water bath at 37 oC for $10 \mathrm{~min}$. Thereafter the mixture was allowed to cool and reading was done with a spectrometer (SP600) at $540 \mathrm{~nm}$ wavelength.

Production of nitric oxide (NO) was evaluated in the heart and kidney tissues using Griess reagent as described by Olaleye et al. (2007). This method involved the addition of $\mathrm{N}$-(1 naphthyl) ethylenediamine and sulfanilic acid to prepare the Griess Reagent, and the mixture of $100 \mu$ of Griess Reagent, $300 \mu$ of the nitrite-containing sample and $2.6 \mathrm{ml}$ of deionized water in a cuvette. Incubation of the mixture was carried out for 30 min at room temperature and a reference sample was prepared by the addition of $100 \mu$ of Griess Reagent and $2.9 \mathrm{ml}$ of deionized water without adding the sample. The absorbance of was measured at $548 \mathrm{~nm}$ wavelength. Myeloperoxidase was determined according to the method of $\mathrm{Xia}$ and Zweier (1997). Reduced glutathione level was evaluated through the method of Ellman (1959), which involved addition of $0.5 \mathrm{ml}$ of $4 \%$ sulfosalicylic acid to $0.5 \mathrm{ml}$ of post mitochondrial fraction of sample and centrifugation for $5 \mathrm{~min}$ at $4,000 \mathrm{rpm}$. The supernatant $(0.5 \mathrm{ml})$ was mixed with $4.5 \mathrm{ml}$ of Ellman's reagent and absorbance was read at $412 \mathrm{~nm}$ wavelength. Glutathione Stransferase activity was determined as described by Habig et al. (1974). Glutathione peroxidase activity was measured according to the method of Buetler et al. (1963). A solution containing $0.5 \mathrm{ml}$ potassium phosphate buffer, $0.1 \mathrm{ml}$ sodium azide, 
$0.2 \mathrm{ml}$ reduced glutathione solution, $0.1 \mathrm{ml}$ hydrogen peroxide, $0.5 \mathrm{ml}$ post mitochondrial fraction of sample and $0.6 \mathrm{ml}$ of distilled water was prepared. The mixture was incubated at $37^{\circ} \mathrm{C}$ for $5 \mathrm{~min}$ and $0.5 \mathrm{ml}$ of trichloro acetic acid was added. Centrifugation was done at 4,000 rpm for 5 min. The supernatant $(1 \mathrm{ml})$ was added to $\mathrm{K}_{2} \mathrm{HPO}_{4}(2 \mathrm{ml})$ and Ellman's reagent $(1 \mathrm{ml})$. The absorbance of the mixture was read at $412 \mathrm{~nm}$ wavelength. Protein carbonyls (PC) were measured using the method of Reznick and Packer (1994). The post mitochondrial fraction of samples $(1 \mathrm{ml})$ were added to two test tubes; one containing $4 \mathrm{ml}$ of 2,4-Dinitrophenylhydrazine and 2.5 M hydrochloric acid whereas the other contained $4 \mathrm{ml}$ of hydrochloric acid. The tubes were incubated at room temperature for 1 hour and vortexed every 15 $\mathrm{min}$. Thereafter, $5 \mathrm{ml}$ of trichloro acetic acid was added and the tubes were placed on ice for $10 \mathrm{~min}$. Centrifugation was then done for $5 \mathrm{~min}$ and the supernatants obtained after centrifugation were carefully removed. The precipitates were dissolved in guanidine hydrochloride solution and are left for 10 min at $37^{\circ} \mathrm{C}$ and vortexed.

The malondialdehyde (MDA) level, a lipid peroxidation index, was determined spectrophotometrically as described by Draper and Hadley (1990). $1.6 \mathrm{ml}$ of Tris-KCl, $0.5 \mathrm{ml}$ of $30 \%$ TCA, $0.4 \mathrm{ml}$ of samples, $0.5 \mathrm{ml}$ of $0.75 \%$ thiobarbituric acid (in $0.2 \mathrm{M} \mathrm{HCl}$ ) were mixed. Incubation was done at $80^{\circ} \mathrm{C}$ for $45 \mathrm{~min}$. The mixture was cooled on ice and centrifuged at 4,000 rpm for $15 \mathrm{~min}$. The absorbance was measured against a blank (distilled water) at $532 \mathrm{~nm}$. Ascorbic acid (vitamin C) determination was performed as described by Jacques-Silva et al. (2001). A solution containing $4.5 \mathrm{mg} / \mathrm{ml}$ dinitrophenyl hydrazine and $0.6 \mathrm{mg} / \mathrm{ml}$ thiourea in a $9 \mathrm{~mol} / \mathrm{L} \mathrm{H}_{2} \mathrm{SO}_{4}$ solution was prepared. Also a second solution was prepared with the addition of $0.075 \mathrm{mg} / \mathrm{ml} \mathrm{CuSO}_{4}$. An aliquot of the sample in a final volume of $1 \mathrm{ml}$ of the solution was incubated for $3 \mathrm{hr}$ at $38{ }^{\circ} \mathrm{C}$, then $1 \mathrm{ml} \mathrm{H}_{2} \mathrm{SO}_{4} 65 \%$ (v/v) was added to the medium.

Superoxide dismutase (SOD) activity was determined by measuring the inhibition of the auto-oxidation of epinephrine at pH 7.2 at 30 OC as described by Misra and Fridovich (1972). This involved dissolving $100 \mathrm{mg}$ of epinephrine in $100 \mathrm{ml}$ distilled water acidified with $0.5 \mathrm{ml}$ concentrated hydrochloric acid. $10 \mu \mathrm{l}$ of post mitochondrial fraction of samples was added to $2.5 \mathrm{ml} 0.05 \mathrm{M}$ carbonate buffer, and $300 \mu \mathrm{l}$ of $0.3 \mathrm{mM}$ adrenaline was added. The increase in absorbance at $480 \mathrm{~nm}$ was monitored every $30 \mathrm{~s}$ for $150 \mathrm{~s}$.

\section{Histopathology}

The heart and kidney of each animal were harvested for routine histopathology. The organs were fixed in 10\% formalin, and then dehydrated with grades of ethanol (70, 80, 90, 95 and 100\%). Dehydration was then followed by clearing the samples in 2 changes of xylene. Samples were then impregnated with 2 changes of molten paraffin wax, then embedded and blocked out. Paraffinembedded, 5-6 $\mu \mathrm{m}$ thick, transverse sections of the heart and kidney were cut using a rotary microtome and mounted on glass slides. The slides were stained with haematoxylin and eosin (H\&E). Stained sections of control and treated rats were examined under the light microscope (Olympus CH Japan) for alterations (Drury et al., 1976).

\section{Statistical Analysis}

All values were expressed as mean \pm standard deviation (SD). The test of significance between two groups was estimated by Student's t-test. Oneway Analysis of Variance (ANOVA) with Tukey's post-hoc test using Graph pad prism 6.0 was also performed with p-values $<0.05$ considered statistically significant.

\section{RESULTS}

The result of the effect of $H$. madagascariensis extract on the blood pressure parameters of rats exposed to sodium fluoride is presented in table 1. The extract significantly $(p<0.05)$ reduced the analysed blood pressure parameters of rats compared with the rats exposed to $\mathrm{NaF}$ without extract treatment (Group B) (Table 1). Also, there was significant increase in the kidney/body weight ratio in the negative control (Group B) when compared with other groups (Table 2). The markers of oxidative stress- malondialdehyde (MDA) and protein carbonyl (PC) increased significantly in the negative control (Group B) compared with the control and other treated groups, but reduced glutathione (GSH) and protein thiol (PT) decreased significantly (Tables 3 
and 4). Markers of oxidative stress increased in the sodium fluoride alone treated group (Group B) when compared with the control and other treated groups, but reduced glutathione (GSH) and protein thiol (PT) decreased significantly (Tables 5 and 6). Serum nitric oxide (NO) decreased significantly in rats exposed to sodium fluoride alone compared with rats that received $200 \mathrm{mg} / \mathrm{kg}$ of $H$. madagascariensis extract (Figure 1). The hydrogen peroxide level increased significantly in cardiac and renal tissues of rats exposed to $\mathrm{NaF}$ alone compared with rats treated with $H$. Madagascariensis extract (Figures 2 and 3). Blood urea nitrogen (BUN) and creatinine increased significantly in rats exposed to sodium fluoride alone compared with rats that received $200 \mathrm{mg} / \mathrm{kg}$
H. madagascariensis as treatment (Table 7).

The histopathology of the cardiac tissue of the rat exposed to sodium fluoride showed mild hydropic/vacuolar degeneration of cardiomyocytes whereas in other groups, cardiomyocytes appear either normal with no visible lesion or with mild infiltration of inflammatory cells. The renal tissue of the exposed rats showed few foci of marked flattening of tubular epithelial cells. There is marked congestion of interstitial blood vessels and glomerular capillary tufts whereas the control and the extract treated groups showed normal glomeruli and tubules.

Table 1: Effect of H. madagascariensis extract on Blood Pressure Parameters of Sodium FluorideInduced Hypertensive Rats

\begin{tabular}{clll}
\hline Groups & SBP $(\mathbf{m m H g})$ & DBP $(\mathbf{m m H g})$ & MAP(mmHg) \\
\hline A & $132.20 \pm 4.15^{\mathrm{b}}$ & $102.00 \pm 5.57^{\mathrm{b}}$ & $115.00 \pm 4.36^{\mathrm{b}}$ \\
B & $169.00 \pm 10.68^{\mathrm{a}}$ & $148.2 \pm 8.76^{\mathrm{a}}$ & $155.2 \pm 9.36^{\mathrm{a}}$ \\
C & $155.80 \pm 6.30^{\mathrm{ab}}$ & $140.60 \pm 3.91^{\mathrm{a}}$ & $148.20 \pm 3.27^{\mathrm{a}}$ \\
D & $123.00 \pm 10.70^{\mathrm{b}}$ & $105.00 \pm 11.34^{\mathrm{b}}$ & $106.80 \pm 11.39^{\mathrm{b}}$ \\
E & $124.20 \pm 25.01^{\mathrm{b}}$ & $116.80 \pm 14.67^{\mathrm{b}}$ & $121.60 \pm 14.67^{\mathrm{b}}$ \\
\hline
\end{tabular}

Values are expressed as mean $\pm \mathrm{SD}, \mathrm{n}=5$. SBP $=$ Systolic Blood Pressure, DBP=Diastolic Blood Pressure, $\mathrm{MAP}=$ Mean Arterial Pressure. Means with the same letters down the column are not significantly different at $\mathrm{P}<0.05$. Group $\mathrm{A}$ (Control), group B (Negative control), group C (Induced + standard drug), group D (Induced $+100 \mathrm{mg} / \mathrm{kg}$ of H. madagascariensis extract) and group E (Induced + $200 \mathrm{mg} / \mathrm{kg}$ of $H$. madagascariensis extract)

Table 2: Effect of H. madagascariensis extract on Organ Weight in Sodium FluorideInduced Hypertensive Rats

\begin{tabular}{|c|c|c|c|c|c|}
\hline Weight & $\mathbf{A}$ & B & $\mathbf{C}$ & D & $\mathbf{E}$ \\
\hline Body weight (g) & $112.5 \pm 5.00^{\mathrm{b}}$ & $117.5 \pm 5.00^{\mathrm{a}}$ & $126 \pm 5.48^{a}$ & $128 \pm 8.37^{a}$ & $140 \pm 10.00^{a}$ \\
\hline Heart (g) & $0.525 \pm 0.050^{\mathrm{b}}$ & $0.500 \pm 0.082^{\mathrm{a}}$ & $0.360 \pm 0.089^{b}$ & $0.500 \pm 0.071^{\mathrm{a}}$ & $0.533 \pm 0.058^{\mathrm{a}}$ \\
\hline Kidney (g) & $0.825 \pm 0.123^{b}$ & $0.875 \pm 0.171^{\mathrm{a}}$ & $0.820 \pm 0.110^{\mathrm{b}}$ & $0.880 \pm 0.110^{\mathrm{a}}$ & $0.967 \pm 0.153^{\mathrm{a}}$ \\
\hline $\begin{array}{l}\text { Heart/Body } \\
\text { weight (g/g) }\end{array}$ & $0.0047 \pm 0.0002^{\mathrm{b}}$ & $0.0043 \pm 0.0009^{a}$ & $0.0028 \pm 0.0006^{\mathrm{ab}}$ & $0.0039 \pm 0.0008^{a}$ & $0.0038 \pm 0.0007^{\mathrm{a}}$ \\
\hline $\begin{array}{l}\text { Kidney/Bod } \\
\text { y weight } \\
(\mathrm{g} / \mathrm{g})\end{array}$ & $0.0073 \pm 0.0012^{\mathrm{b}}$ & $0.0075 \pm 0.0015^{\mathrm{a}}$ & $0.0065 \pm 0.0010^{\mathrm{b}}$ & $0.0069 \pm 0.0011^{\mathrm{b}}$ & $0.0070 \pm 0.0016^{\mathrm{ab}}$ \\
\hline
\end{tabular}

Values are expressed as mean \pm standard deviation; $\mathrm{n}=5 ; \mathrm{g}=$ gram. Means with the same letters down the column are not significantly different at $\mathrm{P}<0.05$. Group A (control), group B (negative control), group C (induced + standard drug), group D (induced $+100 \mathrm{mg} / \mathrm{kg}$ of H. madagascariensis extract) and group $\mathrm{E}$ (induced $+200 \mathrm{mg} / \mathrm{kg}$ of H. madagascariensis extract) 
Table 3: Effect of H. madagascariensis extract on Enzymatic Antioxidants of Cardiac Tissue in Sodium Fluoride-Induced Hypertensive Rats

\begin{tabular}{lccccc}
\hline \multicolumn{1}{c}{ Enzymes } & A & B & C & D & E \\
\hline GST $(\mu \mathrm{mol} / \mathrm{min} /$ & $0.55 \pm 0.42^{\mathrm{b}}$ & $0.95 \pm 0.51^{\mathrm{a}}$ & $0.71 \pm 0.67^{\mathrm{b}}$ & $0.74 \pm 0.56^{\mathrm{ab}}$ & $0.69 \pm 0.47^{\mathrm{b}}$ \\
$\mathrm{mg}$ protein) & & & & & \\
$\mathrm{SOD}(\mu \mathrm{mol} / \mathrm{L})$ & $15.53 \pm 3.21^{\mathrm{b}}$ & $19.97 \pm 4.31^{\mathrm{a}}$ & $17.93 \pm 1.49^{\mathrm{b}}$ & $18.49 \pm 0.99^{\mathrm{ab}}$ & $18.54 \pm 1.31^{\mathrm{ab}}$ \\
$\mathrm{GPx}(\mathrm{units} / \mathrm{mg}$ & $175.50 \pm 26.09^{\mathrm{b}}$ & $222.8 \pm 40.94^{\mathrm{a}}$ & $209.9 \pm 2.87^{\mathrm{b}}$ & $215.00 \pm 7.45^{\mathrm{ab}}$ & $211.90 \pm 14.69^{\mathrm{b}}$ \\
protein) & & & & & \\
\hline
\end{tabular}

Values are expressed as mean \pm standard deviation, $n=5$; means with the same letters down the column are not significantly different at $\mathrm{P}<0.05$. GST-Glutathione S-Transferase, GPx-Glutathione Peroxidase and SOD-Superoxide Dismutase. Group A (control), group B (negative control), group C (induced + standard drug), group D (induced $+100 \mathrm{mg} / \mathrm{kg}$ of H. madagascariensis extract) and group E (induced + $200 \mathrm{mg} / \mathrm{kg}$ of $H$. madagascariensis extract).

Table 4: Effect of H. madagascariensis extract on Enzymatic Antioxidants of Renal Tissue in Sodium Fluoride-Induced Hypertensive Rats

\begin{tabular}{lcccrr}
\hline Enzymes & A & B & C & D & \multicolumn{1}{c}{ E } \\
\hline GST & $1.49 \pm 0.25^{\mathrm{b}}$ & $1.65 \pm 0.36^{\mathrm{a}}$ & $1.36 \pm 0.23^{\mathrm{ab}}$ & $1.49 \pm 0.29^{\mathrm{b}}$ & $1.42 \pm 0.51^{\mathrm{b}}$ \\
SOD & $7.31 \pm 0.81^{\mathrm{b}}$ & $8.44 \pm 1.67^{\mathrm{a}}$ & $7.13 \pm 0.68^{\mathrm{b}}$ & $7.66 \pm 1.50^{\mathrm{b}}$ & $7.89 \pm 1.54^{\mathrm{b}}$ \\
GPx & $84.5 \pm 12.58^{\mathrm{b}}$ & $97.32 \pm 18.87^{\mathrm{a}}$ & $89.05 \pm 8.61^{\mathrm{b}}$ & $92.56 \pm 12.90^{\mathrm{ab}}$ & $94.15 \pm 12.09^{\mathrm{ab}}$ \\
\hline
\end{tabular}

Values are expressed as mean \pm standard deviation, $n=5$; means with the same letters down the column are not significantly different at $\mathrm{P}<0.05$. GST-Glutathione-S-Transferase ( $\mu \mathrm{mol} / \mathrm{min} / \mathrm{mg}$ protein), GPx-Glutathione Peroxidase ( $\mathrm{nmol} / \mathrm{mgHg}$ ) and SOD-Superoxide Dismutase (units/mg protein). Group A (control), group B (negative control), group C (induced + standard drug), group D (induced + $100 \mathrm{mg} / \mathrm{kg}$ of H. madagascariensis extract) and group E (induced $+200 \mathrm{mg} / \mathrm{kg}$ of H. madagascariensis extract).

Table 5: Effect of H. madagascariensis extract on Non-Enzymatic Antioxidants of Cardiac Tissue in Sodium Fluoride-Induced Hypertensive Rats

\begin{tabular}{lccccc}
\hline Enzymes & $\mathbf{A}$ & $\mathbf{B}$ & $\mathbf{C}$ & $\mathbf{D}$ & $\mathbf{E}$ \\
\hline GSH & $88.66 \pm 6.18^{\mathrm{b}}$ & $71.20 \pm 6.61^{\mathrm{a}}$ & $90.82 \pm 4.77^{\mathrm{b}}$ & $86.24 \pm 8.02^{\mathrm{b}}$ & $87.83 \pm 5.55^{\mathrm{b}}$ \\
MDA & $6.22 \pm 1.13^{\mathrm{b}}$ & $8.05 \pm 2.50^{\mathrm{a}}$ & $7.55 \pm 1.50^{\mathrm{a}}$ & $7.37 \pm 1.15^{\mathrm{ab}}$ & $6.61 \pm 4.21^{\mathrm{b}}$ \\
PC & $6034.59 \pm$ & $8486.27 \pm$ & $7222.01 \pm$ & $6902.72 \pm$ & $6686.12 \pm$ \\
& $1859.99^{\mathrm{b}}$ & $2173.16^{\mathrm{a}}$ & $4210.10^{\mathrm{ab}}$ & $4555.32^{\mathrm{b}}$ & $2587.86^{\mathrm{b}}$ \\
PT & $38.01 \pm 4.68^{\mathrm{b}}$ & $34.19 \pm 19.06^{\mathrm{a}}$ & $40.94 \pm 20.03^{\mathrm{ab}}$ & $39.82 \pm 18.15^{\mathrm{b}}$ & $40.70 \pm 18.32^{\mathrm{b}}$ \\
\hline
\end{tabular}

Values are expressed as mean \pm standard deviation, $n=5$. Means with the same letters down the column are not significantly different at $\mathrm{P}<0.05$. GSH-Reduced Glutathione, MDA-Malondialdehyde, PTProtein Thiol and PC-Protein Carbonyl. Group A (control), group B (negative control), group C (induced + standard drug), group D (induced $+100 \mathrm{mg} / \mathrm{kg}$ of H. madagascariensis extract) and group E (induced $+200 \mathrm{mg} / \mathrm{kg}$ of $H$. madagascariensis extract) $\mathrm{GSH}=$ Reduced Glutathione ( $\mu \mathrm{mol} / \mathrm{mgprotein}$ ); $\mathrm{MDA}=$ Malondialdehyde (nmol $/ \mathrm{mg}$ protein); $\mathrm{PC}=$ Protein Carbonyl (nmol $/ \mathrm{mg}$ protein); $\mathrm{PT}=$ Protein Thiol $=(\mu \mathrm{mol} / \mathrm{mg}$ protein $)$. 
Table 6: Effect of $H$. madagascariensis extract on Non-Enzymatic Antioxidants of Renal Tissue in Sodium Fluoride-Induced Hypertensive Rats

\begin{tabular}{lccccc}
\hline Enzymes & A & B & C & D & E \\
\hline GSH & $99.26 \pm 6.84^{\mathrm{b}}$ & $88.40 \pm 28.83^{\mathrm{a}}$ & $96.84 \pm 5.39^{\mathrm{ab}}$ & $99.91 \pm 11.57^{\mathrm{b}}$ & $98.56 \pm 16.95^{\mathrm{b}}$ \\
MDA & $6.01 \pm 3.36^{\mathrm{b}}$ & $8.49 \pm 8.64^{\mathrm{a}}$ & $5.31 \pm 4.32^{\mathrm{b}}$ & $4.02 \pm 3.53^{\mathrm{ab}}$ & $5.62 \pm 8.72 \mathrm{~b}^{\mathrm{a}}$ \\
PC & $9472.57 \pm$ & $10368.3 \pm$ & $9654.58 \pm$ & $9036.71 \pm$ & $9478.34 \pm$ \\
& $3380.60^{\mathrm{b}}$ & $4096.62^{\mathrm{a}}$ & $3326.48^{\mathrm{b}}$ & $5480.52^{\mathrm{b}}$ & $4559.98^{\mathrm{b}}$ \\
PT & $99.81 \pm 17.1^{\mathrm{b}}$ & $90.07 \pm 34.35^{\mathrm{a}}$ & $115.30 \pm 33.20^{\mathrm{b}}$ & $111.10 \pm 15.4^{\mathrm{ab}}$ & $115.7 \pm 25.49^{\mathrm{ab}}$ \\
\hline
\end{tabular}

Values are expressed as mean \pm standard deviation, $n=5$. Means with the same letters down the column are not significantly different at $\mathrm{P}<0.05$. Group A (control), group $\mathrm{B}$ (negative control), group $\mathrm{C}$ (induced + standard drug), group D (induced $+100 \mathrm{mg} / \mathrm{kg}$ of H. madagascariensis extract) and group E (induced $+200 \mathrm{mg} / \mathrm{kg}$ of $H$. madagascariensis extract). GSH= Reduced Glutathione ( $\mu \mathrm{mol} / \mathrm{mg}$ protein); $\mathrm{MDA}=$ Malondialdehyde $(\mathrm{nmol} / \mathrm{mg}$ protein) $; \mathrm{PC}=$ Protein Carbonyl (nmol $/ \mathrm{mg}$ protein); $\mathrm{PT}=$ Protein Thiol $=(\mu \mathrm{mol} / \mathrm{mg}$ protein $)$.

Table 7: Effect of H. madagascariensis Extract on Analysed Markers of Kidney Function in Sodium Fluoride-Induced Hypertensive Rats

\begin{tabular}{lccccc}
\hline Markers & A & B & C & D & E \\
\hline BUN & $16.93 \pm 0.40^{\mathrm{b}}$ & $17.68 \pm 1.52^{\mathrm{a}}$ & $15.98 \pm 0.88^{\mathrm{ab}}$ & $17.43 \pm 0.69^{\mathrm{a}}$ & $16.75 \pm 0.44^{\mathrm{b}}$ \\
$\mathbf{( m m o l} / \mathbf{d l})$ & & $0.88 \pm 0.15^{\mathrm{a}}$ & $0.68 \pm 0.08^{\mathrm{ab}}$ & $0.78 \pm 0.05^{\mathrm{b}}$ & $0.75 \pm 0.06^{\mathrm{b}}$ \\
$\begin{array}{l}\text { CREATININE } \\
(\mathbf{m m o l} / \mathbf{d l})\end{array}$ & $0.78 \pm 0.05^{\mathrm{b}}$ & 0.75 & & & \\
\hline
\end{tabular}

Values are expressed as mean \pm standard deviation, $\mathrm{n}=5$. Group $\mathrm{A}$ (control), group B (negative control), group C (induced + standard drug), group D (induced $+100 \mathrm{mg} / \mathrm{kg}$ of H. madagascariensis extract) and group E (induced $+200 \mathrm{mg} / \mathrm{kg}$ of H. madagascariensis extract). BUN = Blood Urea Nitrogen.

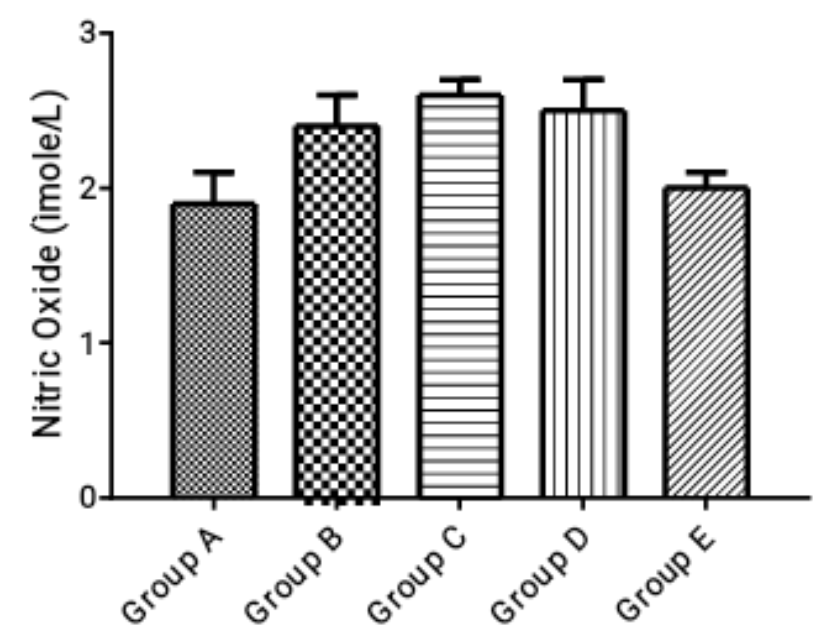

Figure 1: The effect of $H$. Madagascariensis on Serum Nitric Oxide (NO) of Sodium Fluoride Exposed Rats

Group A (control), group B (negative control), Group C (induced + standard drug), Group D (induced $+100 \mathrm{mg} / \mathrm{kg}$ of $H$. madagascariensis extract) and Group $\mathrm{E}$ (induced $+200 \mathrm{mg} / \mathrm{kg}$ of $H$. madagascariensis extract) 


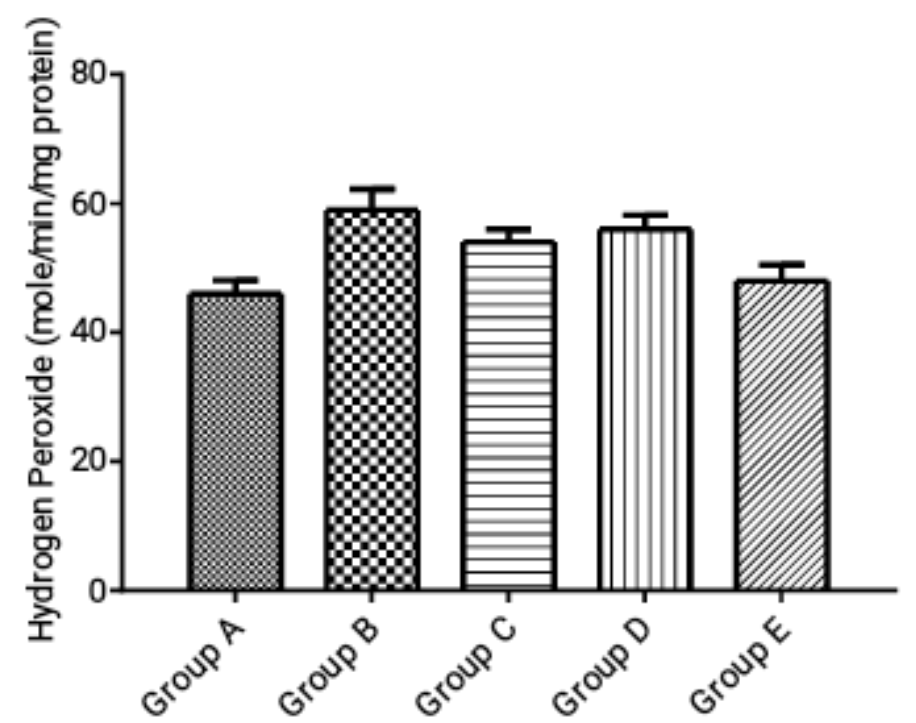

Fig 3: The effect of $H$. madagascariensis extract on the Renal Tissue of Sodium Fluoride Exposed Rats

Group A (control), group B (negative control), Group C (induced + standard drug), Group D (induced $+100 \mathrm{mg} / \mathrm{kg}$ of $H$. madagascariensis extract) and Group $\mathrm{E}$ (induced $+200 \mathrm{mg} / \mathrm{kg}$ of $H$. madagascariensis extract)
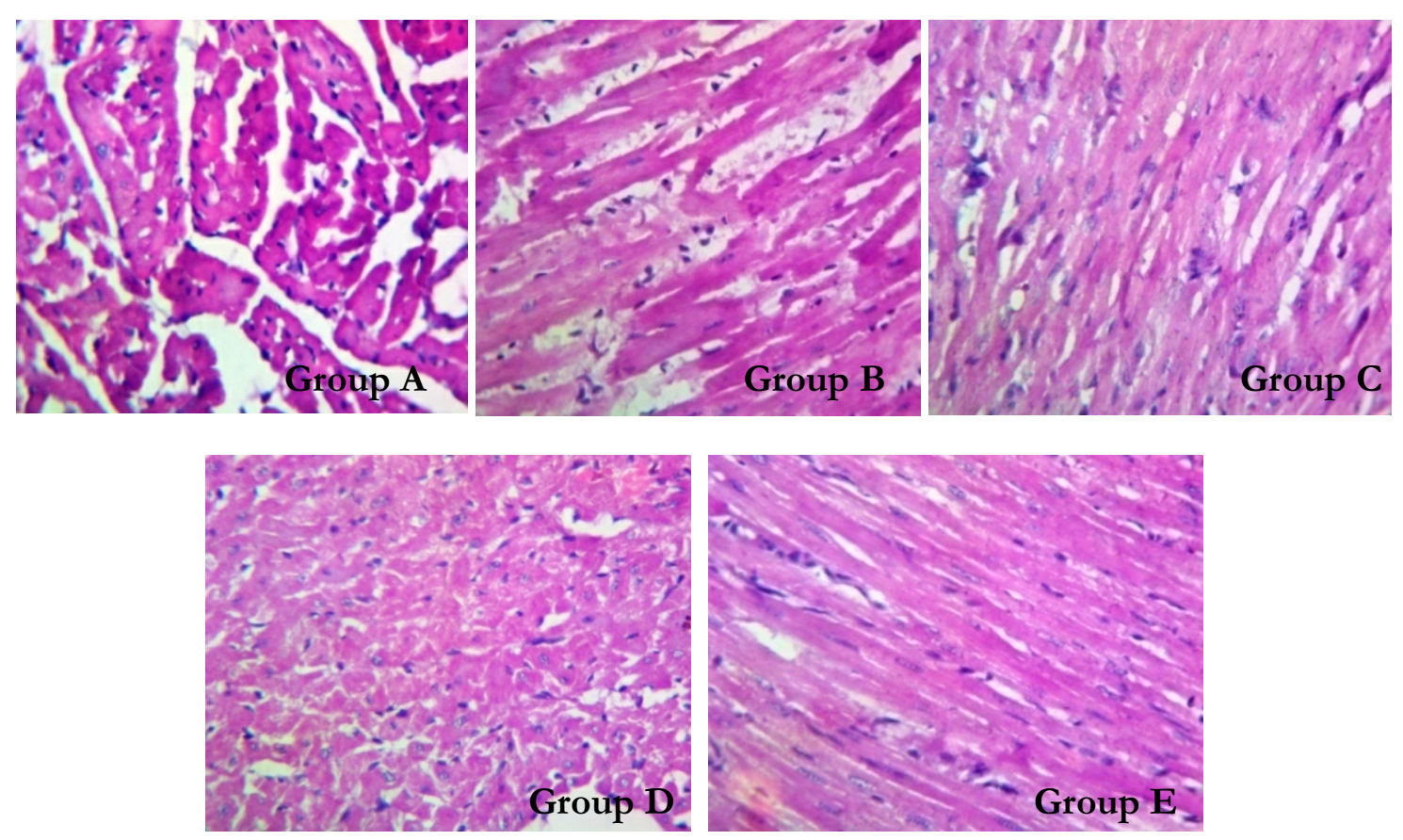

Figure 4: Effect of $H$. madagascariensis extract on Histology of Cardiac Tissue of Sodium Fluoride-Induced Hypertensive Rats 

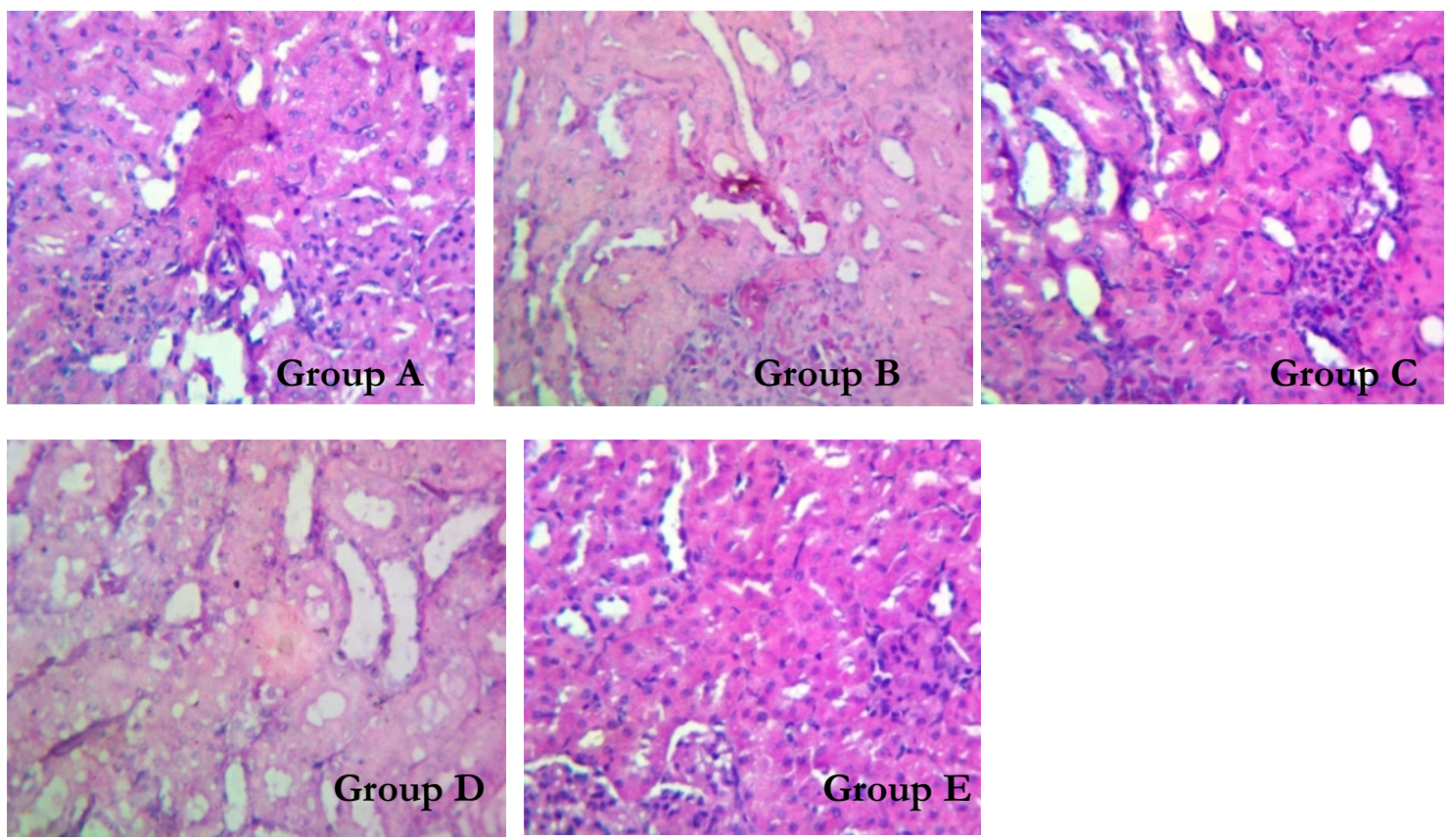

Figure 5: Effect of $H$. madagascariensis extract on Histology of Renal Tissue of Sodium Fluoride-Induced Hypertensive Rats

\section{DISCUSSION}

In this study, there was a significant difference between the systolic blood pressure (SBP), diastolic blood pressure (DBP) and mean arterial pressure (MAP) of the normotensive rats and the hypertensive rats in relation to the $H$. madagascariensis stem bark extract treated groups. The reduction of the SBP, DBP and MAP suggest an antihypertensive effect for the plant extract (Mojiminiyi et al., 2007). There was significant increase in the kidney/body weight ratio in the negative control when compared with other groups. This is not in agreement with the work of Oyagbemi et al. (2016) who reported a significant decrease in the kidney/body ratio of rats exposed to sodium fluoride $(\mathrm{NaF})$. This may be as a result of the level of exposure or the positive effect exhibited by the extract of $H$. madagascariensis stem bark when compared with the treated group and control. Sodium fluoride is known to target the kidneys which serve as the primary organs involved in its excretion and retention (Song et al., 2014). It is documented that fluoride salt induces toxic effects in target organs such as the liver and kidney (Santoyo-Sanchez et al., 2013). The increase in the kidney/body weight of rats observed in this study may be due to the hypertensive effect caused by the exposure to sodium fluoride but were ameliorated by the administration of enalapril and the extract of $H$. madagascariensis stem bark. Furthermore, this study revealed significant changes in the activities of the enzymatic and non enzymatic antioxidants in the cardiac and renal tissues. Antioxidant enzymes such as superoxide dismutase (SOD), catalase (CAT) and glutathione peroxidase (GPx) protect cells from toxic reactive oxygen species (Mates et al., 1999). The presence of endogenous GSH and antioxidant enzymes such as CAT, GPx and GST has been suggested to be responsible for the elimination of hydrogen peroxide $\left(\mathrm{H}_{2} \mathrm{O}_{2}\right)$ and other toxic substances in biological systems (Sharma et al., 2012). The biochemical function of GPx is to reduce lipid hydroperoxides to their corresponding alcohols and to reduce free $\mathrm{H}_{2} \mathrm{O}_{2}$ to water. Peroxidase possesses high affinity for and can remove $\mathrm{H}_{2} \mathrm{O}_{2}$ even when it is present in low concentration, and SOD activity enhances the spontaneous dismutation of superoxide radicals to $\mathrm{H}_{2} \mathrm{O}_{2}$ (Kohen and Nyska, 2002). In addition, the GPx and GST are key enzymes that take part in maintaining glutathione homeostasis in the tissues. GPx and GST as antioxidant enzymes work together with GSH in the decomposition of $\mathrm{H}_{2} \mathrm{O}_{2}$ and other organic hydro peroxides (Zhou et al., 2016). Decrease in SOD activity could result from inactivation by $\mathrm{H}_{2} \mathrm{O}_{2}$ or by glycation of the enzyme, which has been reported to occur in 
diabetes and hypertension (Sozmen et al., 2001) as a result of depletion owing to excessive use of these enzymes to mop up the hypertensioninduced free radical generation. In this study, the observed increased activity of GST, GPx and SOD may be due to the activations caused by the reactive oxygen species.

Also in this study, the markers of oxidative stress malondialdehyde (MDA) and protein carbonyl (PC) increased significantly in the positive control compared with treatment groups, but reduced glutathione (GSH) and protein thiol (PT) decreased significantly. Observation in this study corroborates the earlier report of Nwanjo et al. (2007) who reported increase in plasma MDA level, which is a marker of lipid peroxidation due to oxidative stress in sodium fluoride $(\mathrm{NaF})$ induced hypertension. The elevated MDA levels observed in this study may be due to the production of superoxide, peroxyl, and hydroxyl radicals as earlier suggested by Abdel-Wahhab et al. (2017). Increased peroxidation of membrane lipids is one of principal consequences of oxidative damage produced by $\mathrm{NaF}$ exposure (Ameeramja et al., 2018). Elevated levels of protein carbonyl are believed to be caused by increased oxidation of protein due to oxidative stress (Yaidikar and Thakur, 2015). Reduced glutathione (GSH) is present at high concentrations in all mammalian cells, especially in the renal cells, hepatocytes, and erythrocytes (Sehirli et al., 2008). GSH is one of the most important endogenous intracellular antioxidants. It plays the role of a sulfhydryl (SH) group provider for direct scavenging reactions. The decrease in the protein thiol is indicative of enhanced protein oxidation in the renal tissue which might be associated with systemic oxidative stress (Manna and Jain, 2015).

Also in this study, there was a significant decrease in the serum nitric oxide (NO) of the positive control group when compared to the treated groups. The reduced NO bioavailability has been documented to precipitate hypertension (Chalupsky et al., 2015). Human hypertension is associated in a decrease in nitric oxide (NO) bioavailability and an increase in oxidative stress (Touyz and Schiffrin, 2004). Nitric oxide is released by the endothelium and causes vascular relaxation (Rafieian-Kopaei et al., 2014). The significant increase in blood urea nitrogen (BUN) and creatinine in the sodium fluoride-exposed rats may be due to increased protein catabolism resulting from sodium fluoride-induced systemic oxidative damage. This suggests extensive glomerular damage and tubular epithelial cells damage which may also reduce the rate of creatinine clearance from the kidneys and equally its retention in the blood circulation (Seelhammer etal., 2016).

\section{CONCLUSION}

Harungana madagascariensis extract showed hypotensive and antioxidant effects in sodium fluoride-induced hypertensive rats. The plant might be useful in the management of hypertension caused by oxidative stress. However, more clinical studies in human are still required to further validate its efficacy.

\section{REFERENCES}

Abdel-Wahhab, M. A., Helmy, M.S., Ahmed, S.H. and Abdel-Aziem, A.A. 2017. Modulation of hepatotoxicity, DNA fragmentation and gene expression of Solanum nigrum leaves extract in rats treated with silver nanoparticles Journal of Applied Pharmacentical Science, 7:025-035.

Ameeramja, J., Kanagaraj, V.V. and Perumal, E. 2018. Protocatechuic acid methyl ester modulates fluoride induced pulmonary toxicity in rats. Food and Chemical Toxicology, 118: 235-244.

Ayah, R., Joshi, M.D., Wanjiru, R., Njau, E.N., Otieno, C.F., Njeru, E.K., Mutai, K. 2013. A population-based survey of prevalence of diabetes and correlates in an urbanslum community in Nairobi, Kenya. BMC Public Health, 13: 371-381.

Barbier, O., Arreola-Mendoza, L. and Del Razo, L.M. 2010. Molecular mechanisms of fluoride toxicity. Chemical and Biological Interactions, 188: 319-33.

Buetler, E., Duron, O. and Kelly, B.M. 1963. Improved method for the determination of blood glutathione, Journal of Laboratory and Clinical Medicine, 61: 882-888.

Carretero, O.A. and Oparil, S. 2000. Essential hypertension. Part I: Definition and 
etiology. Circulation Journal, 101:329-35.

Chalupsky, K. and Cai, H. 2005. Endothelial dihydrofolate reductase: critical for nitric oxide bioavailability and role in angiotensin II uncoupling of endothelial nitric oxide synthase. Proceedings of National Academy of Science US A, 102: 9056-61.

Das, S.S., Maiti, R., Ghosh, D. 2008. Fluorideinduced immunotoxicity in adult male albino rat: a correlative approach to oxidative stress. Journal of Immunotoxicology, 3:49-55.

Dayanand, G., Sharma, A., Ahmed, M., Jyothi, P.P. and Rani, M. 2015. Effect of banana on blood pressure of hypertensive individuals: a cross sectional study from Pokhara. Nepal Medical Science Journal, 3:233-237

Draper, H.H. and Hadley M. 1990. Malondialdehyde determination as index of lipid peroxidation. Methods in Enzymology, 186: 421-31.

Drury, R.A., Wallington, E.A., Cancerson, R. 1976. Carlton's histopathological techniques, 4th Edition, Oxford, London, New York: Oxford University Press.

Ellman, G. L. 1959. Tissue sulfhydryl groups. Archive Biochemistry and Biophysics, 82:70 77.

Farías, J.G., Molina, V.M., Carrasco, R., Zepeda A.B., Figueroa E., Letelier P., Castillo R.L. 2017. Antioxidant therapeutic strategies for cardiovascular conditions associated with oxidative stress. Nutrients, 9:1-23.

Ghosh, R., Lurmann, F., Perez, L., Penfold, B., Brandt, S. 2016. Near-Roadway air pollution and coronary heart disease: burden of disease and potential impact of a greenhouse gas reduction strategy in southern California. Environmental Health Perspective, 124, 193-200.

Gornal, A.G., Bardawill, J.C., David, M.M. 1949. Determination of serum proteins by means of biuret reaction. Journal of Biological Chemistry, 177: 751-766.

Gyamlani, G. and Geraci, S.A. 2007. Secondary hypertension due to drugs and toxins. South Medical Journal, 100:692-699.

Habig, W. H., Pabst, M. J., and Jakoby, W. B. 1974. Glutathione S-transferases. The first enzymatic step in mercapturic acid formation. Journal of Biological Chemistry, 25:7130-7139.

Iwalewa, E.O., Omisore, N.O., Adewunmi, C.O., Gbolade, A.A., Ademowo, O.G., Nneji, C., Agboola, O.I. and Daniyan, O.M. 2008. Anti-protozoan activities of Harungana madagascariensis stem bark extract on trichomonads and malaria. Journal of Ethnopharmacology, 22: 507-511.

Jacques-Silva, M.C., Nogueira, C.W., Broch, L.C., Flores, E.M. and Rocha, J.B. 2001. Diphenyl diselenide and ascorbic acid changes deposition of selenium and ascorbic acid in liver and brain of mice. Pharmacology and Toxicology, 88: 119-25.

Kahn, L.G. and Trasande, L. 2018. Environmental toxicant exposure and hypertensive disorders of pregnancy: recent findings. Current Hypertension Reports, 20: 87-96.

Kearney, P.M., Whelton, M., Reynolds, K., Muntner, P., Whelton, P.K. and He, J. 2005. Global burden of hypertension: analysis of worldwide data. Lancet, 365: 217-23.

Kohen, R. and Nyska, A. 2002. Oxidation of biological systems: oxidative stress phenomena, antioxidants, redox reactions, and methods for their quantification. Toxicology and Pathology, 30: 620-50.

Manna, P. and Jain, S. K. 2015. Obesity, oxidative stress, adipose tissue dysfunction, and the associated health risks: causes and therapeutic strategies. Metabolic Syndrome and RelatedDisorders, 13: 423-444.

Mates, J.M., Perez-Gomez, C., De Castro, I.N. 1999. Antioxidant enzymes and human diseases. Clinical Biochemistry, 32:595-603.

Misra, H.P. and Fridovich I. 1972. The role of superoxide anion in the autooxidation of epinephrine and a simple assay for superoxide dismutase. Journal of Biological Chemistry, 247:3170-3175.

Mojiminiyi, F.B., Dikko, M., Muhammad, B.Y., Ojobor, P.D. and Ajagbonna, O.P. 2007. Antihypertensive effect of an aqueous extract of the calyx of Hibiscus sabdariffa, Fitoterapia, 78: 292-297.

Moronkola, D.O., Yeboah, S.O., Majinda, R.R.T., Yeboah, E., Fru, C.G. and Osamudiamen 
P.M. 2018. antioxidant properties of the methanol extracts of leaf, stem, fruit and seed of Nigerian Harungana madagascariensis, an Hypericaceae (Gutiferae). European Journal of Pharmacology, 5: 123-127.

Njar, V.C.O, Alao, T.O, Okogun, J.I. and Holland, H.L. 1993. 2 methoxycanthin-6-one: a new alkaloid from the stem wood of Quassia amara. Planta Medica, 59: 259-261.

Nwanjo, H.U., Oze, G., Okafor, M.C., Nwasu, D. and Nwankpa, P. 2007. Oxidative stress and non enzymic antioxidant status in hypertensive patients in Nigeria. African Journal of Biotechnology, 6:1681-1684.

Olaleye, S.B., Adaramoye, O.A., Erigbali, P.P. and Adeniyi OS. 2007. Lead exposure increases oxidative stress in the gastric mucosa of $\mathrm{HCl} /$ ethanol-exposed rats. World Journal of Gastroenterology, 13:5121-5126.

Oyagbemi, A.A., Omobowale, T.O., Asenuga, E.R. Adejumobi A.O., Ajibade, T.O., Ige, T.M. 2016. Sodium fluoride induces hypertension and cardiac complications through generation of reactive oxygen species (ROS) and activation of nuclearfactor kappa beta $(\mathrm{NF}-\mathrm{kB})$. Environmental Toxicology, 32:1089-1101.

PHS (PUBLIC HEALTH SERVICE). 1996. Public Health Service Policy on humane care and the use of laboratory animals. US Department of Health and Humane Services, Washington, DC, pp 99-158.

Rafieian-Kopaei M. 2014. In vitro evaluation of antioxidant properties of ten Iranian medicinal plants. Iran Red Crescent Medical Journal, 16:1-2.

Reznick, A.Z. and Packer L. 1994. Oxidative damage to proteins: spectrophotometric method for carbonyl assay. Methods in Enzymology, 233: 357-363.

Sadhukhan, P., Saha, S. and Sil. P.C. 2016. Antioxidative effect of Genistein and Mangiferin on sodium fluoride induced oxidative insult of renal cells: a comparative study. Biomarkers Journal, 2:112.

Santoyo-Sánchez, M. P, Carmen Silva-Lucero, M., Barbier. O.C. 2013. Effects of acute sodium fluoride exposure on kidney function, water homeostasis, and renal handling of calcium and inorganic phosphate. Biological Trace Element Research, 152:367-372.

Seelhammer, T.G., Maile, M.D. and Heung M. 2016. Kinetic estimated glomerular filtration rate and acute kidney injury in cardiac surgery patients. Journal of Critical Care, 31:249-254.

Sehirli, O., Tatlidede E., Yuksel M., Erzik C., Cetinel S., Yegen B.C. and Sener, G. 2008. Antioxidant effect of alpha-lipoic acid against ethanol-induced gastric mucosal erosion in rats. Pharmacology, 81: 173-180.

Sharma, P., Jha, A.B., Dubey, R.S. and Pessarakli, M. 2012. Reactive oxygen species, oxidative damage, and antioxidative defense mechanism in plants under stressful conditions. Journal of Botany, 2012:1-26.

Simeon, K.F., Yapna, D.B., Krohn, K., Ngadjui, B.T., Ngoupayo, J., Choudhary, M.I. and Schulz, B. 2007. Antimicrobial prenylated anthraacene derivatives from the leaves of Harungana madagascariensis. Journal of NaturalProducts, 70: 600-603.

Song C., Cao X., Yang Z., Guo S., Shang Z. 2013. Fluoride-induced cell cycle arrest, apoptosis, and DNA damage in TM3 mouse Leydig cells. Fluoride, 46:218-223.

Suska, M. 2001. The effect of sodium fluoride on the adenine nucleotide pool in erythrocytes of Wistar rats. International Journal of Occupational Medical and Environmental Health, 14:369-373.

Tabassum, N. and Ahmad F. 2011. Role of natural herbs in the treatment of hypertension. Pharmacognosy Review, 5: 30-40.

Tom, E.N.L., Mimb, J.R.B., Nyuna ¿, N., Bekono, Y.F. and Longo, F. 2018. Vasodilatory effects of aqueous extract from Harungana madagascariensis stem bark in isolated rat aorta: the roles of endothelium and $\mathrm{K}+$ channels. American Journal of Ethnomedicine. 5:1-7.

Touyz, R.M. and Schiffrin, E.L. 2004. Reactive oxygen species in vascular biology: implications in hypertension. Histochemical and Cellular Biology. 122: 339-352.

Xia, Y. and Zweier JL. 1997. Measurement of 
myeloperoxidase in leukocyte-containing tissues. Analytical Biochemistry, 245:93-96.

Yaidikar, L. and Thakur, S. 2015. Arjunolic acid, a pentacyclic triterpenoidal saponin of Terminalia arjuna bark protects neurons from oxidative stress associated damage in focal cerebral ischemia and reperfusion. Pharmacology Reports, 67:890-895.

Zhou, S., Sorokina, E.M., Harper, S., Li, H., Ralat,
L., Dodia, C., Speicher, D.W., Feinstein S.I.and Fisher, A.B. 2016. Peroxiredoxin 6 homodimerization and heterodimerization with glutathione S-transferase pi are required for its peroxidase but not phospholipase A2 activity. Free Radicals in Biology and Medicine, 94:145-56. 